\title{
NON-ARCHIMEDEAN HYPERSTABILITY OF A CAUCHY-JENSEN TYPE FUNCTIONAL EQUATION
}

\author{
MuAadh Almahalebi
}

Abstract. In this paper, we establish some hyperstability results concerning the following Cauchy

- Jensen functional equation

$$
f\left(\frac{x+y}{2}\right)+f\left(\frac{x-y}{2}\right)=f(x)
$$

in Non-Archimedean normed spaces. equation.

Mathematics subject classification (2010): Primary 39B82; Secondary 39B52, 47H10.

Keywords and phrases: stability, hyperstability, Non-Archimedean space, Cauchy-Jensen functional

\section{REFERENCES}

[1] M. Almahalebi, A. Charifi And S. KABBAJ, Hyperstability of a monomial functional equation, Journal of Scientific Research Reports, 3, 20 (2014), 2685-2693.

[2] M. Almahalebi AND S. KABBAJ, Hyperstability of Cauchy-Jensen type functional equation, Advances in Research, 2, 12 (2014), 1017-1025.

[3] M. Almahalebi And C. PARK, On the hyperstablity of a functional equation in commutative groups, Journal of Computational Analysis and Applications, 20, 5 (2016), 826-833.

[4] M. Almahalebi, A. Charifi And S. KabBaJ, Hyperstability of a Cauchy functional equation, Journal of Nonlinear Analysis and Optimization, 6, 2 (2015), 127-137.

[5] M. Almahalebi, On the hyperstability of $\sigma$-Drygas functional equation on semigroups, Aequationes math., 90, 4 (2016), 849-857.

[6] T. AOKI, On the stability of the linear transformation in Banach spaces, J. Math. Soc. Japan, 2, (1950), 64-66.

[7] C. BAAK, Cauchy-Rassias stability of Cauchy-Jensen additive mappings in Banach spaces, Acta Math. Sin. (Engl. Ser.), 22, 6 (2006), 1789-1796.

[8] A. BAhyrycZ, J. BRZDȨK AND M. PiszCZEK, On approximately p-Wright afine functions in ultrametric spaces, J. Funct. Spaces Appl., 2013, Art. ID 723545.

[9] A. BAhyrycz And J. OLKO, Stability of the equation of $(p, q)$-Wright functions, Acta Math. Hung., 146, (2015), 71-85.

[10] A. BAhyrycz And J. Olko, On stability of the general linear equation, Aequationes Math., 89, (2015), 1461-1474.

[11] A. BAHYRYCZ AND M. PISZCZEK, Hyperstability of the Jensen functional equation, Acta Math. Hungar., 142, (2014), 353-365.

[12] D. G. Bourgin, Approximately isometric and multiplicative transformations on continuous function rings, Duke Math. J., 16, (1949), 385-397.

[13] J. BRZDȨK, Stability of additivity and fixed point methods, Fixed Point Theory and App., 2013, 2013:285, 9 pages.

[14] J. BRZDȨK, Hyperstability of the Cauchy equation on restricted domains, Acta Math. Hungar., 141, (2013), 58-67.

[15] J. BRZDȨK, Remarks on hyperstability of the Cauchy functional equation, Aequationes Math., 86, (2013), 255-267. 
[16] J. BRZDȨK, A hyperstability result for the Cauchy equation, Bull. Aust. Math. Soc., 89, (2014), 33-40.

[17] J. BRZDȨK, J. CHUDZIAK AND Zs. PÁLES, A fixed point approach to stability of functional equations, Nonlinear Anal., 74, (2011), 6728-6732.

[18] J. BRZDȨK AND K. CIEPLIŃSKI, A fixed point approach to the stability of functional equations in non-Archimedean metric spaces, Nonlinear Analysis, 74, (2011), 6861-6867.

[19] J. BRZdȩK AND K. CieplińsKi, Hyperstability and superstability, Abs. Appl. Anal., 2013, Article ID 401756, 13 pp., (2013).

[20] P. GăVRUŢA, A generalization of the Hyers-Ulam-Rassias stability of approximately additive mappings, J. Math. Anal. Appl., 184, (1994), 431-436.

[21] M. E. GordJi, H. KhOdAEI AND M. KAMYAR, Stability of Cauchy-Jensen type functional equation in generalized fuzzy normed spaces, Computers and Mathematics with Applications, 62, (2011), 29502960.

[22] E. Gselmann, Hyperstability of a functional equation, Acta Math. Hungar., 124, (2009), 179-188.

[23] D. H. Hyers, On the stability of the linear functional equation, Proc. Natl. Acad. Sci. U.S.A., 27, (1941), 222-224.

[24] B. JESSEN, J. KARPF AND A. Thorup, Some functional equations in groups and rings, Math. Scand., 22, (1968), 257-265.

[25] K. - W. Jun, H. -M. Kim And J. M. Rassias, Extended Hyers-Ulam stability for Cauchy-Jensen mappings, J. Diference Equ. Appl, 13, 12 (2007), 1139-1153.

[26] A. Khrennikov, Non-Archimedean Analysis: Quantum Paradoxes, Dynamical Systems and Biological Models., Kluwer Academic Publishers, Dordrecht, 1997.

[27] Gy. MAKs A AND Zs. PÁLEs, Hyperstability of a class of linear functional equations, Acta Math., 17, 2 (2001), 107-112.

[28] C. PARK, Fixed points and Hyers-Ulam-Rassias stability of Cauchy-Jensen functional equations in Banach algebras, Fixed Point Theory and Applications, (2007), 15 pages. Article ID 50175.

[29] C. PARK AND J. M. Rassias, Stability of the Jensen-type functional equation in $C^{*}$-algebras: a fixed point approach, Abs. Appl. Anal, (2009) 17 pages. Article ID 360432.

[30] M. PISZCZEK, Remark on hyperstability of the general linear equation, Aequationes math., 88, 1 (2014), 163-168.

[31] TH. M. Rassias, On the stability of the linear mapping in Banach spaces, Proc. Amer. Math. Soc., 72, (1978), 297-300.

[32] M. Sirouni And S. KabBaJ, A fixed point approach to the hyperstability of Drygas functional equation in metric spaces. J. Math. Comput. Sci., 4, 4 (2014), 705-715.

[33] S. M. Ulam, Problems in Modern Mathematics, Science Editions, John-Wiley \& Sons Inc., New York, 1964.

[34] D. ZHANG, On Hyers-Ulam stability of generalized linear functional equation and its induced HyersUlam programming problem, Aequationes Math., 90, (2016), 559-568.

[35] D. ZHANG, On hyperstability of generalised linear functional equations in several variables, Bull. Aust. Math. Soc., 92, (2015), 259-267. 